\title{
Residual Effect of Boron on Quality and Post Harvest Parameters of Knol- Khol (Brassica oleracea Var.Gongylodes L.) in Coastal Regions of Odisha
}

\author{
Rabi Shankar Panda ${ }^{1}$, Dipika Sahoo ${ }^{1 *}$, B. Jena ${ }^{2}$, G.S. Sahu ${ }^{1}$, \\ P. Tripathy ${ }^{1}$, R.K. Nayak $^{2}$, N.R.Sahoo ${ }^{3}$ and M.P. Das ${ }^{1}$
}

${ }^{1}$ Department of Vegetable Science, College of Agriculture, Odisha University of Agriculture and technology, Bhubaneswar-751003, India

${ }^{2}$ AICRP on Micronutrients, Department of Soil Science \& Agriculture Chemistry, College of Agriculture, Odisha University of Agriculture and technology, Bhubaneswar-751003

${ }^{3}$ AICRP on Post Harvest Engineering and Technology, O.U.A.T. Bhubaneswar-751003

*Corresponding author

\section{Keywords}

Residual, Boron, quality, Post harvest parameters, Knol khol

Article Info

Accepted:

15 August 2019

Available Online:

10 September 2019

\section{A B S T R A C T}

A long term field experiment was started during 2012-13 at E block of central research station, under AICRP on Micronutrient, O.U.A.T, Bhubaneswar to standardize the dose and frequency of boron application for rice-knol khol cropping system where boron is applied to first crop and Knol khol gets residual boron. In the present investigation residual effect of different graded doses of boron and its frequency of application on quality and post harvest parameters of Knol khol for the year 2017-18 was studied. The experiment was laid out in a Factorial Randomized Block Design with three replications and four different doses of boron $(0.5 \mathrm{~kg} / \mathrm{ha}, 1.0 \mathrm{~kg} / \mathrm{ha}, 1.5 \mathrm{~kg} / \mathrm{ha}$ and $2.0 \mathrm{~kg} / \mathrm{ha})$ at three different frequencies (application of boron once, alternate year and every year) were applied. The results revealed that the maximum values of quality and post harvest parameters (viz., Total soluble solid content of knob $\left(6.7^{\circ}\right.$ Brix), Ascorbic acid content of knob (78.2 $\mathrm{mg} / 100 \mathrm{~g})$, Firmness of knob (7.9kgf), Dry matter content $(9.21 \%)$, Duration of maximum retention of shelf life of knob (5.03 days), Percentage of marketable knobs (96.1\%) with no knob cracking were recorded with residual effect of boron @ $1.5 \mathrm{~kg} / \mathrm{ha}$ in every year application. The knob cracking increased as the Boron availability decreased.

\section{Introduction}

Knol khol (Brassica oleracea var. gongylodes L.) a member of the cole crops belongs to family Brassicaceae and is of north-european origin. The modified stem tuber of Knol khol which constituted edible portion is fairly rich in carbohydrates, proteins, minerals like calcium, magnesium, phosphorus, sodium, sulphur, etc. It also contains the antioxidants, vitamin A, C, E and carotene and is a good source of dietary fibre. It also contains sulphoraphanes and other isothiocyanates which are believed to stimulate the production of protective enzymes in the body. In Odisha, it is grown in some patches covering an area of 0.306 lakh ha out of total $0.87 \mathrm{M}$ ha vegetable cultivated area (Odisha Ag. 
Statistics 2016-17). With increasing population, the demand of Knol khol has significantly increased, but the production, productivity and quality has remained low in Odisha due to lack of use of balanced fertilization, less use efficiency of most nutrients, non inclusion of micronutrients in the fertilization schedule etc. Boron is an essential plant micronutrient for cell division and is also an important constituent of cell membrane. Deficiency of boron causes abnormal cell division at the points which especially lead to disorder like cracking in Knol khol. From GPS based soil survey and analysis by AICRP on Micronutrient, OUAT, Bhubaneswar in 2017, it was observed that boron deficiency was wide spread in different soils of all the district of Odisha and varied from $(8-79) \%$ and is a major constraint in vegetable production (Satisha and Ganeshamurthy, 2012). In the present study residual effect of boron was studied since its leaching is a common process in light texture sandy loam soil during kharif. Thus, growing of a shallow rooted crop like rice as direct crop followed by a semi-deep to deep rooted crop like Knol khol can utilize leached Boron efficiently from subsoil (Das, 2000) thereby benefitting both rice and Knol khol. Farmers in coastal Odisha generally grow Knol khol after rice and apply $\mathrm{B}$ frequently to both rice and knol khol as the production of Knol khol is lower in the areas of low B fertility. In most of the cases direct response of boron on Knol khol are studied by several workers Therefore, it is desirable to obtain information on effects of residual B on succeeding deep rooted crop that may be responsive to high levels of $B$ in soil. Limited information is available on residual effect of $B$ fertilization on quality and post harvest parameters of Knol khol under rice-knol khol cropping system. Till now no proper method and dose of boron is standardized for a long term rice based vegetable cropping system regarding whether to apply small quantities every year or bulk quantity once and skip its application to alternate years. Hence, keeping in view the above facts a long term experiment was started during 2012-13 under AICRP on Micronutrients on rice-vegetable cropping system which is continuing for six years. The proposed research work is confined to 201718 cropping season of the above project, O.U.A.T, Bhubaneswar by taking different graded doses of Boron which are applied over different frequencies to rice-knol khol cropping system which is continuing for six years.

\section{Materials and Methods}

The experiment was conducted during kharif and rabi season of the year 2017-18 at E block of central research station, O.U.A.T, Bhubaneswar, which is situated at $20^{\circ} 15^{\prime \prime} \mathrm{N}$ latitude and $85^{\circ} 52$ " E longitude with elevation of $25.9 \mathrm{~m}$ above MSL (Mean sea level). The experimental site comes under the agro-climatic zone East and South Eastern Coastal plain of Odisha and East Coastal Plains and Hills zone of the humid tropics of India. The soil in the study area belongs to a textural class of sandy loam and low in nitrogen, phosphorus, potassium and boron content with a $\mathrm{pH}$ of 5.40 which is slightly acidic.

The experiment was laid out in Factorial Randomized Block Design with three replications and thirteen treatments (Table 1). 21 days old seedlings of Knol khol variety white Vienna were planted with a spacing of $40 \mathrm{~cm}$ X $30 \mathrm{~cm}$ in the afternoon hours immediately followed by irrigation for proper establishment of the seedlings in the specified plots. Observations were recorded on quality and post harvest parameters like TSS content ( ${ }^{\circ}$ Brix), Ascorbic acid content $(\mathrm{mg} / 100 \mathrm{~g})$, Firmness (kgf), Dry Matter content, Duration of maximum retention of shelf life (days), Percentage of marketable knobs (\%) and 
Percentage of knob cracking (\%). The data so generated was statistically analysed.

\section{Results and Discussion}

Residual effect of graded doses and frequency of boron application on Quality and post-harvest parameters of Knol khol

The results of the present studies (Table 3) revealed that the quality and post-harvest parameters of Knol khol like total soluble solid content of knob, ascorbic acid content of knob, firmness of knob, dry matter content of knob, duration of maximum retention of shelf life of knob, percentage of marketable knobs and percentage of knob cracking were significantly influenced by graded doses and frequency of boron application. The maximum total soluble solid (Fig. 1) content of knob (6. $7^{\circ}$ Brix), ascorbic acid (Fig. 2) content of knob (78.2 mg/100g), firmness (Fig. 3) of knob (7.9 kgf), dry matter content (Fig. 4) of knob $(9.21 \%)$, duration of maximum retention of shelf life (Fig. 5) of knob (5.03 days), percentage of marketable knobs (Fig. 6) (96.17 \%) with no percentage of knob cracking (Fig. 7) $(0 \%)$ were noticed by $\mathrm{D}_{3} \mathrm{~F}_{3}$ (residual application of $1.5 \mathrm{~kg}$ boron every year) which was significantly superior to all other treatments and at par with $\mathrm{D}_{4} \mathrm{~F}_{2}$ (residual application of $2 \mathrm{~kg} / \mathrm{ha}$ boron in alternate year) in characters total soluble solid content of knob $\left(5.9^{\circ}\right.$ Brix), ascorbic acid content of knob $(75.4 \mathrm{mg} / 100 \mathrm{~g})$ and firmness of knob (7.1 $\mathrm{kgf})$. All these parameters were found minimum except percentage of knob cracking (10.27\%, Table 2) which was found maximum in the control plots where no boron was applied.

Boron application significantly improves the quality and post harvest parameters of Knol khol. This might be due to increased concentration of nutrients in plant under boron fertilization. Adequate supply of nutrients with optimum dose of boron might have better effect on utilization of more nutrients as compared to lower and higher doses of boron application. This resulted in an increase in quality and post harvest parameters of Knol khol. It is an established fact that nutrient uptake by the crop depends primarily on boron accumulation and secondary nutrient concentration at cellular levels, as boron is concerned with translocation of sugar, complex compounds like carbohydrates etc. with greater ease. The increase in photosynthetic efficiency results in more dry matter production and more nutrient concentration in plants that seems to be major factor responsible for higher quality and post harvest parameters under the influence of boron application (Blevins and Lukaszewski, 1998; Goldbach and Wimmer, 2007).

Above results were similar with findings of Saha et al., (2010) on quality and post-harvest parameters of Knol khol like total soluble solid content of knob, ascorbic acid content of knob, dry matter content of knob and percentage of marketable knobs increased significantly under boron fertilization. Improved ascorbic acid content in cauliflower curd was seen with increased boron levels due to improved physiological activity and catalytic action (Singh et al., 2002). Similar results were also reported by Mehrotra et al., (1974) in cauliflower, Kumar et al., (2002) in cauliflower, Abd EL-ALL (2014), Islam et al., (2015) and Ain et al., (2016) in broccoli. Percentage of knob cracking was significantly influenced by insufficient supply of boron since boron is a constituent of cell membrane that is essential for cell division. In case of boron deficiency cell division ceases at the growing point which especially lead to disorder like knob cracking in knol khol (Shah et al., 2010), hollow stem and browning in cauliflower (Singh, 1991). With decrease in Boron availability to crop the cracking percentage increased. 
Table.1 Detail of treatments

\begin{tabular}{|c|c|}
\hline $\mathbf{T}_{1}$ & 0.5kg Boron applied per ha once (2012-2013) \\
\hline $\mathbf{T}_{2}$ & $1 \mathrm{~kg}$ Boron applied per ha once (2012-2013) \\
\hline $\mathbf{T}_{3}$ & 1.5kg Boron applied per ha once (2012-2013) \\
\hline $\mathbf{T}_{4}$ & 2kg Boron applied per ha once (2012-2013) \\
\hline $\mathbf{T}_{5}$ & 0.5 kg Boron applied per ha in alternate year (2016-2017) \\
\hline$T_{6}$ & $1 \mathrm{~kg}$ Boron applied per ha in alternate year (2016-2017) \\
\hline $\mathbf{T}_{7}$ & 1.5kg Boron applied per ha in alternate year (2016-2017) \\
\hline $\mathbf{T}_{8}$ & 2kg Boron applied per ha in alternate year (2016-2017) \\
\hline $\mathbf{T}_{9}$ & 0.5kg Boron applied per ha every year (2017-2018) \\
\hline $\mathbf{T}_{10}$ & $1 \mathrm{~kg}$ Boron applied per ha every year (2017-2018) \\
\hline $\mathbf{T}_{11}$ & 1.5kg Boron applied per ha every year (2017-2018) \\
\hline $\mathbf{T}_{12}$ & 2kg Boron applied per ha every year (2017-2018) \\
\hline $\mathbf{T}_{13}$ & Control (No Boron application) \\
\hline
\end{tabular}

Note: $100 \%$ RDF (100:75:75) NPK kg/ha was Common to all treatments of Knol khol.

The fertilizer B is applied to the first crop of the cropping system (Rice).

Starting Year: 2012

Study Year: 2017-18

Table 2 Residual effect of graded doses and frequency of boron application on quality and post harvest parameters of Knol khol

\begin{tabular}{|c|c|c|c|c|c|c|c|}
\hline Treatment & $\begin{array}{c}\text { TSS } \\
\text { content } \\
\left({ }^{\circ} \text { Brix }\right)\end{array}$ & $\begin{array}{l}\text { Ascorbic } \\
\text { acid } \\
\text { content } \\
\text { (mg/ } \\
100 \mathrm{~g})\end{array}$ & $\begin{array}{c}\text { Firmness } \\
\text { (kgf) }\end{array}$ & $\begin{array}{c}\text { Dry } \\
\text { Matter } \\
\text { content } \\
(\%)\end{array}$ & $\begin{array}{l}\text { Duration of } \\
\text { maximum } \\
\text { retention of } \\
\text { shelf life } \\
\text { (days) }\end{array}$ & $\begin{array}{c}\text { Percentage } \\
\text { of } \\
\text { marketable } \\
\text { knobs }(\%)\end{array}$ & $\begin{array}{c}\text { Percentage } \\
\text { of knob } \\
\text { cracking } \\
(\%)\end{array}$ \\
\hline $\mathbf{D}_{1}$ & 5.10 & 56.90 & 5.68 & 6.12 & 3.26 & 73.09 & 3.29 \\
\hline$D_{2}$ & 5.26 & 62.35 & 6.18 & 6.69 & 3.61 & 76.10 & 2.10 \\
\hline$D_{3}$ & 5.87 & 66.73 & 6.54 & 7.37 & 3.87 & 80.97 & 1.12 \\
\hline $\mathbf{D}_{4}$ & 5.67 & 62.44 & 6.29 & 6.73 & 3.74 & 75.71 & 1.31 \\
\hline $\mathrm{SE}(\mathrm{m}) \pm$ & 0.16 & 1.22 & 0.15 & 0.08 & 0.05 & 0.61 & 0.09 \\
\hline C.D.(0.05) & 0.48 & 3.57 & 0.44 & 0.22 & 0.14 & 1.77 & 0.26 \\
\hline $\mathbf{F}_{1}$ & 5.20 & 50.59 & 5.47 & 5.59 & 2.68 & 65.01 & 3.10 \\
\hline $\mathbf{F}_{2}$ & 5.41 & 65.15 & 6.33 & 7.04 & 3.88 & 80.53 & 1.43 \\
\hline $\mathbf{F}_{3}$ & 5.81 & 70.59 & 6.74 & 7.55 & 4.31 & 83.87 & 1.33 \\
\hline $\mathrm{SE}(\mathbf{m}) \pm$ & 0.19 & 1.41 & 0.17 & 0.09 & 0.06 & 0.70 & 0.10 \\
\hline C.D.(0.05) & 0.55 & 4.12 & 0.51 & 0.26 & 0.17 & 2.04 & 0.31 \\
\hline MEAN & 5.73 & 62.10 & 6.18 & 6.73 & 3.62 & 76.47 & 1.96 \\
\hline CONTROL & 4.83 & 46.95 & 4.90 & 4.10 & 2.17 & 49.97 & 10.27 \\
\hline C vrs R SE (d) \pm & 0.33 & 2.54 & 0.31 & 0.16 & 0.10 & 1.26 & 0.19 \\
\hline C.D.(0.05) & 0.70 & 5.25 & 0.65 & 0.33 & 0.21 & 2.60 & 0.39 \\
\hline
\end{tabular}


Table 3 Interaction residual effect of graded doses and frequency of boron application on quality and post harvest parameters of Knol khol

\begin{tabular}{|c|c|c|c|c|c|c|c|}
\hline Treatment & $\begin{array}{c}\text { TSS } \\
\text { content } \\
\left({ }^{\circ} \text { Brix }\right)\end{array}$ & $\begin{array}{l}\text { rbic } \begin{array}{l}\text { acid } \\
\text { content } \\
(\mathrm{mg} / 100 \mathrm{~g})\end{array}\end{array}$ & $\begin{array}{c}\text { Firmness } \\
\text { (kgf) }\end{array}$ & $\begin{array}{l}\text { Dry } \\
\text { Matter } \\
\text { content } \\
\\
(\%)\end{array}$ & $\begin{array}{c}\text { Duration } \\
\text { of } \\
\text { maximum } \\
\text { retention } \\
\text { of shelf life } \\
\text { (days) }\end{array}$ & $\begin{array}{c}\text { Percentage } \\
\text { of } \\
\text { marketable } \\
\text { knobs }(\%)\end{array}$ & $\begin{array}{c}\text { Percentage } \\
\text { of knob } \\
\text { cracking } \\
(\%)\end{array}$ \\
\hline $\mathbf{D}_{1} \mathbf{F}_{1}$ & 4.5 & 49.3 & 5.2 & 5.15 & 2.27 & 62.50 & 5.18 \\
\hline $\mathbf{D}_{2} \mathbf{F}_{1}$ & 5.4 & 49.6 & 5.5 & 5.61 & 2.63 & 64.50 & 3.75 \\
\hline$D_{3} F_{1}$ & 5.4 & 52.1 & 5.4 & 5.74 & 2.67 & 65.37 & 2.85 \\
\hline $\mathbf{D}_{4} \mathbf{F}_{1}$ & 5.5 & 51.4 & 5.7 & 5.87 & 3.13 & 67.67 & 1.95 \\
\hline$D_{1} F_{2}$ & 5.2 & 53.3 & 5.7 & 6.19 & 3.30 & 76.23 & 2.43 \\
\hline $\mathbf{D}_{2} \mathbf{F}_{2}$ & 5.0 & 61.9 & 6.2 & 6.71 & 3.70 & 79.17 & 2.13 \\
\hline $\mathbf{D}_{3} \mathbf{F}_{2}$ & 5.5 & 69.9 & 6.3 & 7.15 & 3.90 & 81.37 & 1.17 \\
\hline $\mathbf{D}_{4} \mathbf{F}_{2}$ & 5.9 & 75.4 & 7.1 & 8.12 & 4.60 & 85.33 & 0.65 \\
\hline$D_{1} F_{3}$ & 5.6 & 68.1 & 6.2 & 7.02 & 4.20 & 80.53 & 2.27 \\
\hline $\mathbf{D}_{2} \mathbf{F}_{3}$ & 5.3 & 75.6 & 6.8 & 7.74 & 4.50 & 84.63 & 0.93 \\
\hline $\mathbf{D}_{3} \mathbf{F}_{3}$ & 6.7 & 78.2 & 7.9 & 9.21 & 5.03 & 96.17 & 0 \\
\hline $\mathbf{D}_{\mathbf{4}} \mathbf{F}_{3}$ & 5.6 & 60.6 & 6.1 & 6.21 & 3.50 & 74.13 & 2.13 \\
\hline $\mathrm{SE}(\mathrm{m}) \pm$ & 0.33 & 2.44 & 0.30 & 0.15 & 0.99 & 1.21 & 0.18 \\
\hline C.D.(0.05) & 0.95 & 7.13 & 0.88 & 0.44 & 0.29 & 3.53 & 0.53 \\
\hline
\end{tabular}

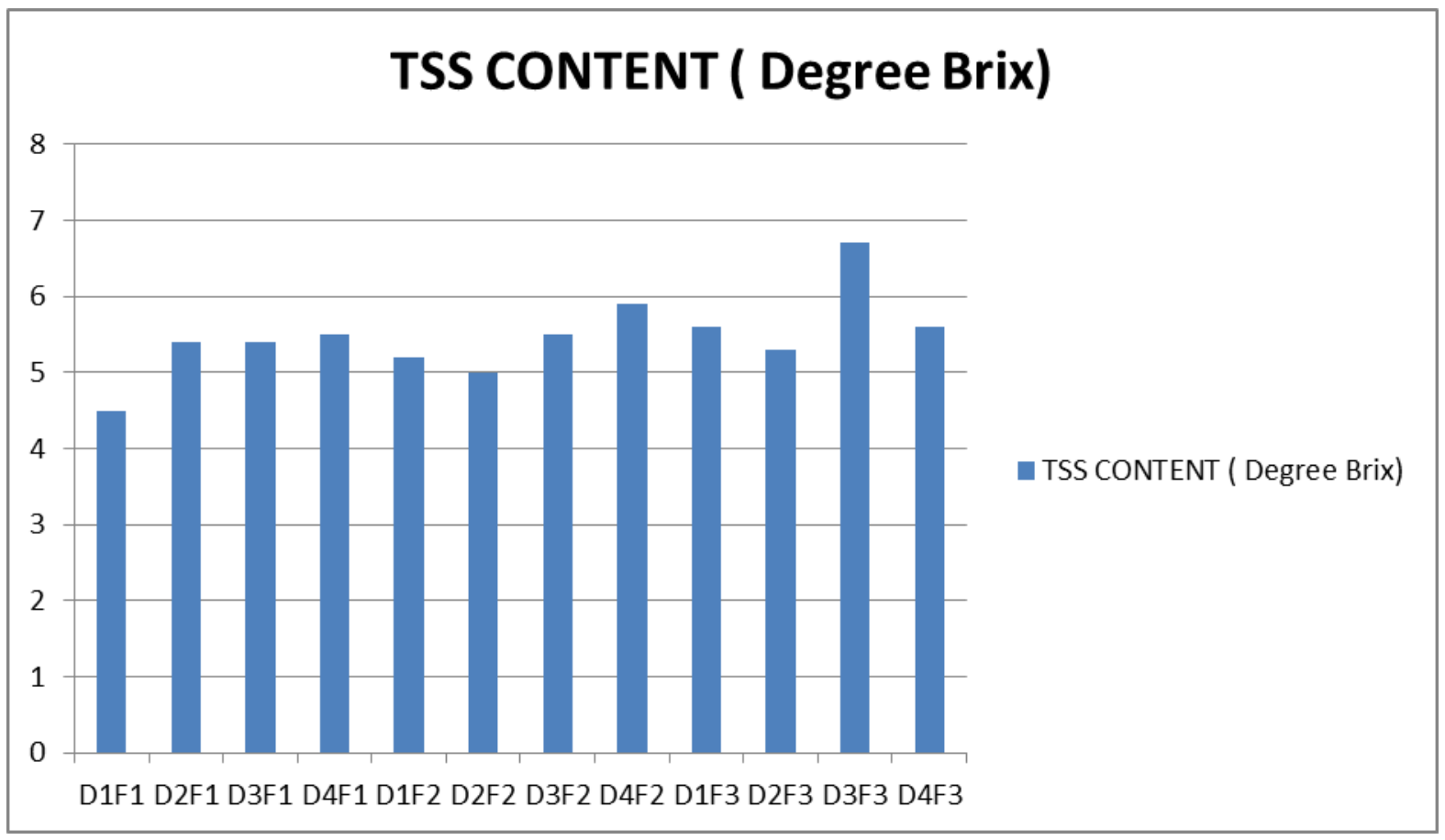

Figure.1 Residual effect of graded doses and frequency of boron application on total soluble solid content of Knol khol knob 


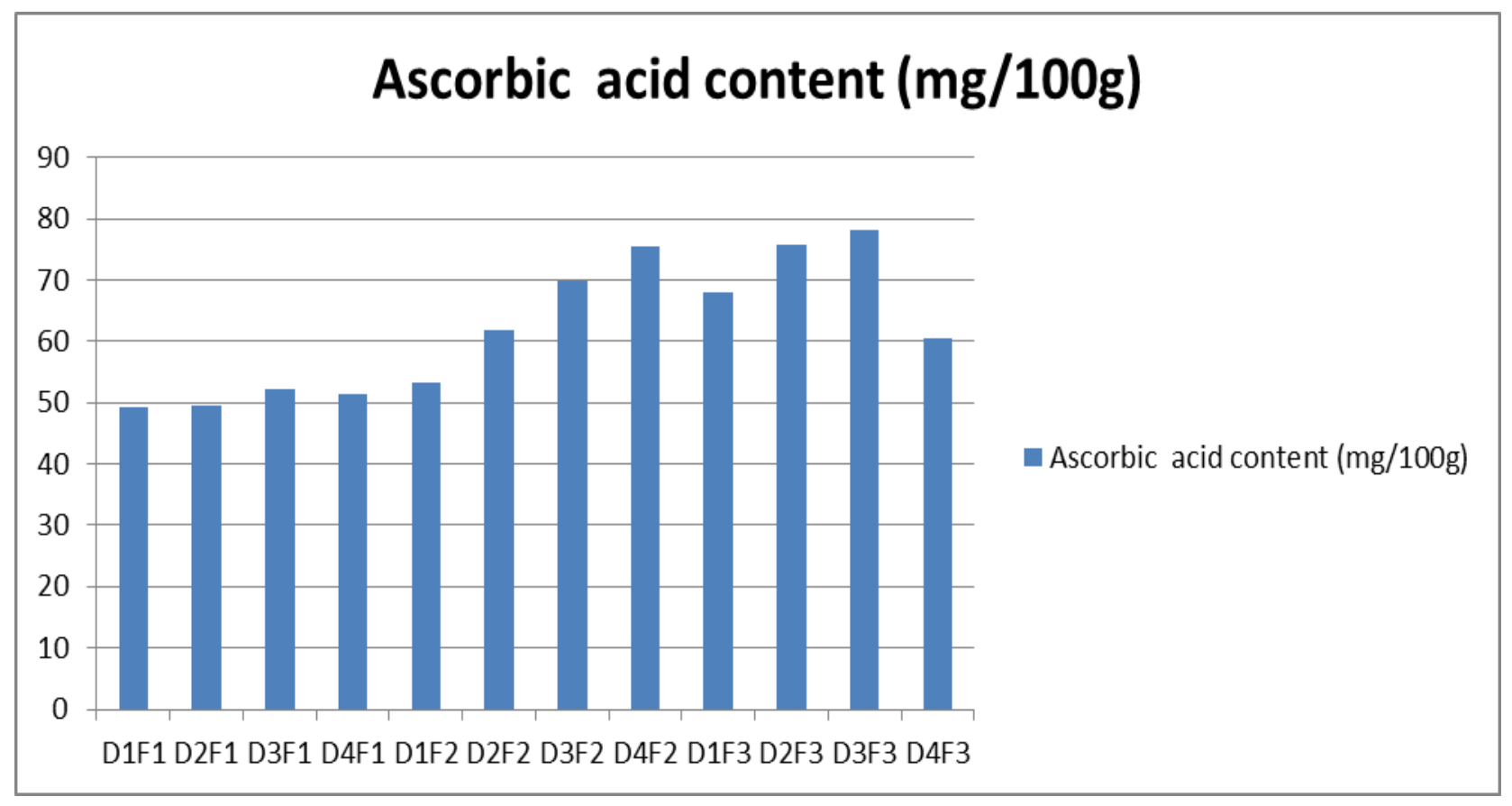

Figure.2 Residual effect of graded doses and frequency of boron application on ascorbic acid content of knol khol knob

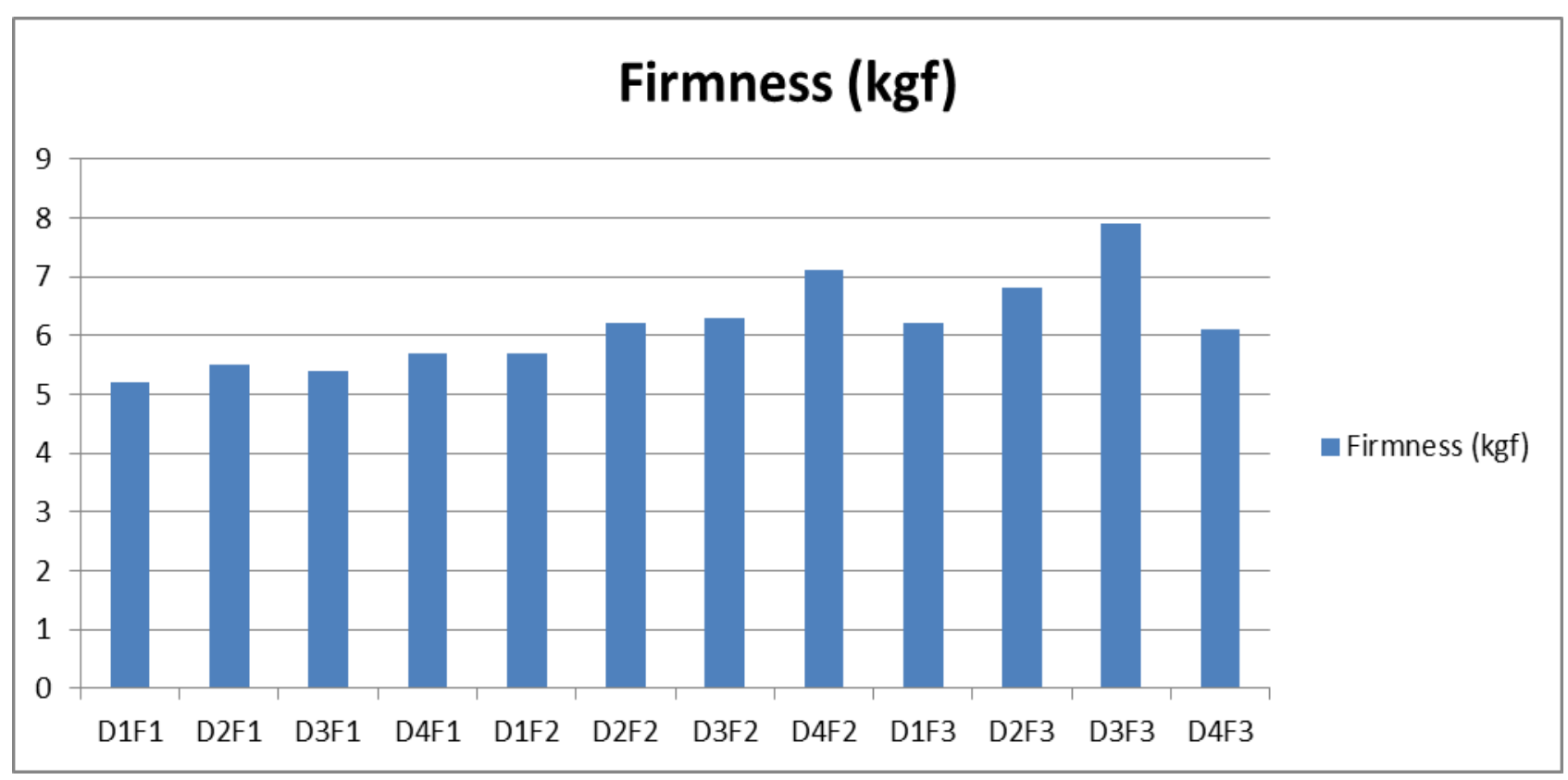

Figure.3 Residual effect of graded doses and frequency of boron application on firmness of Knol khol knob 


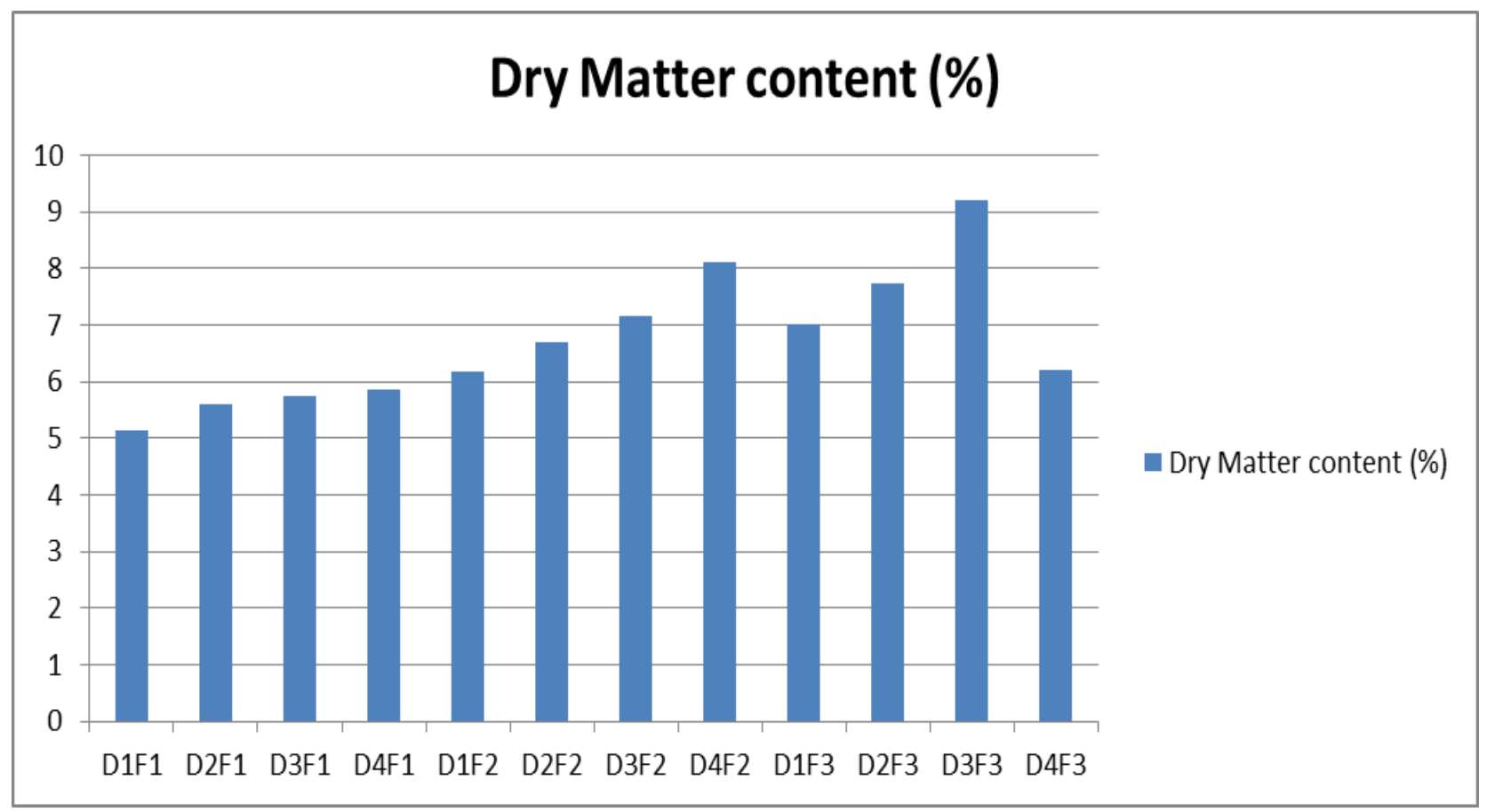

Figure.4 Residual effect of graded doses and frequency of boron application on dry matter content of Knol khol knob

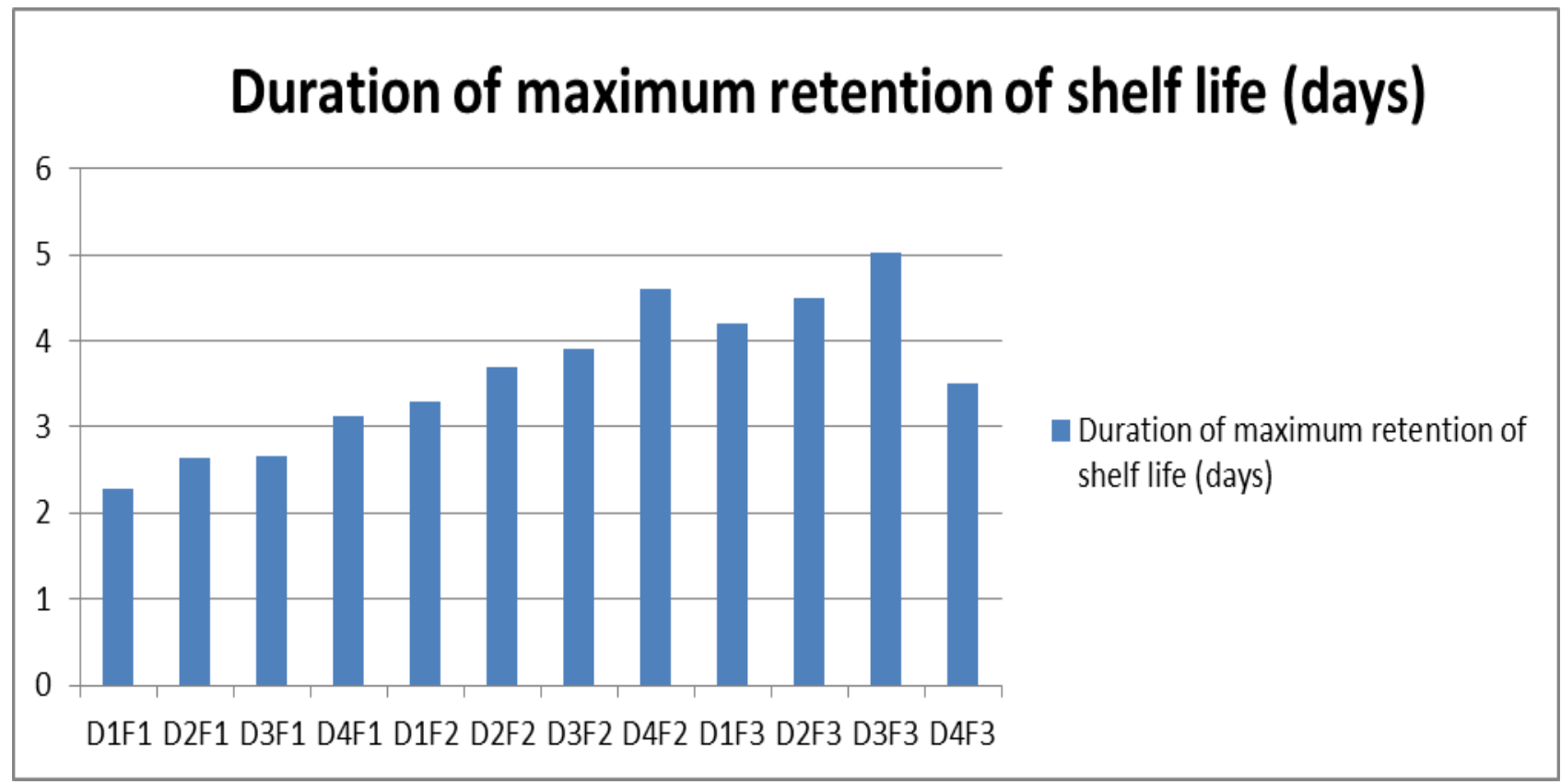

Figure.5 Residual effect of graded doses and frequency of boron application on duration of maximum retention of shelf life of Knol khol knob 


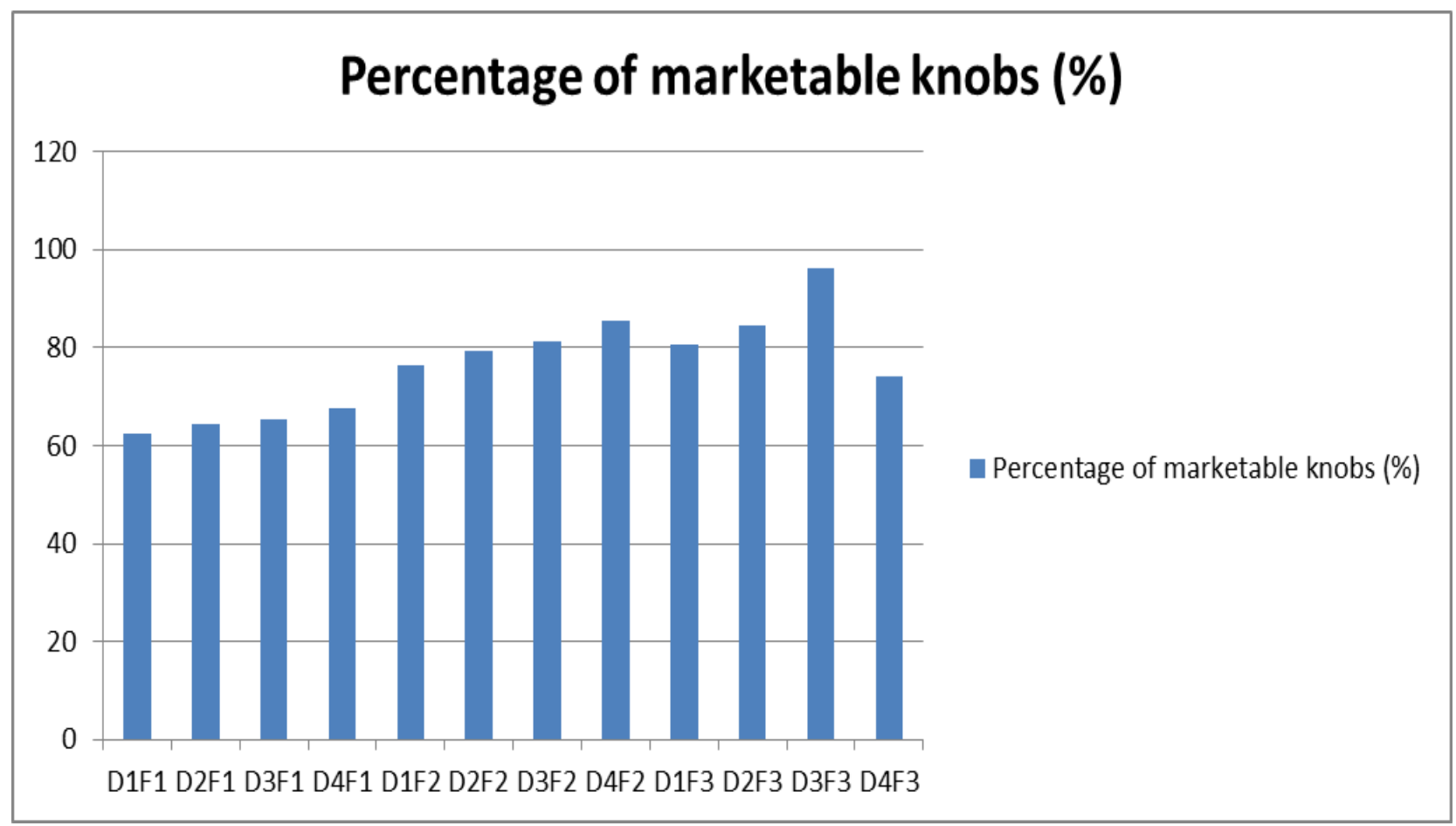

Figure.6 Residual Effect of graded doses and frequency of boron application on percentage of marketable Knol khol knob

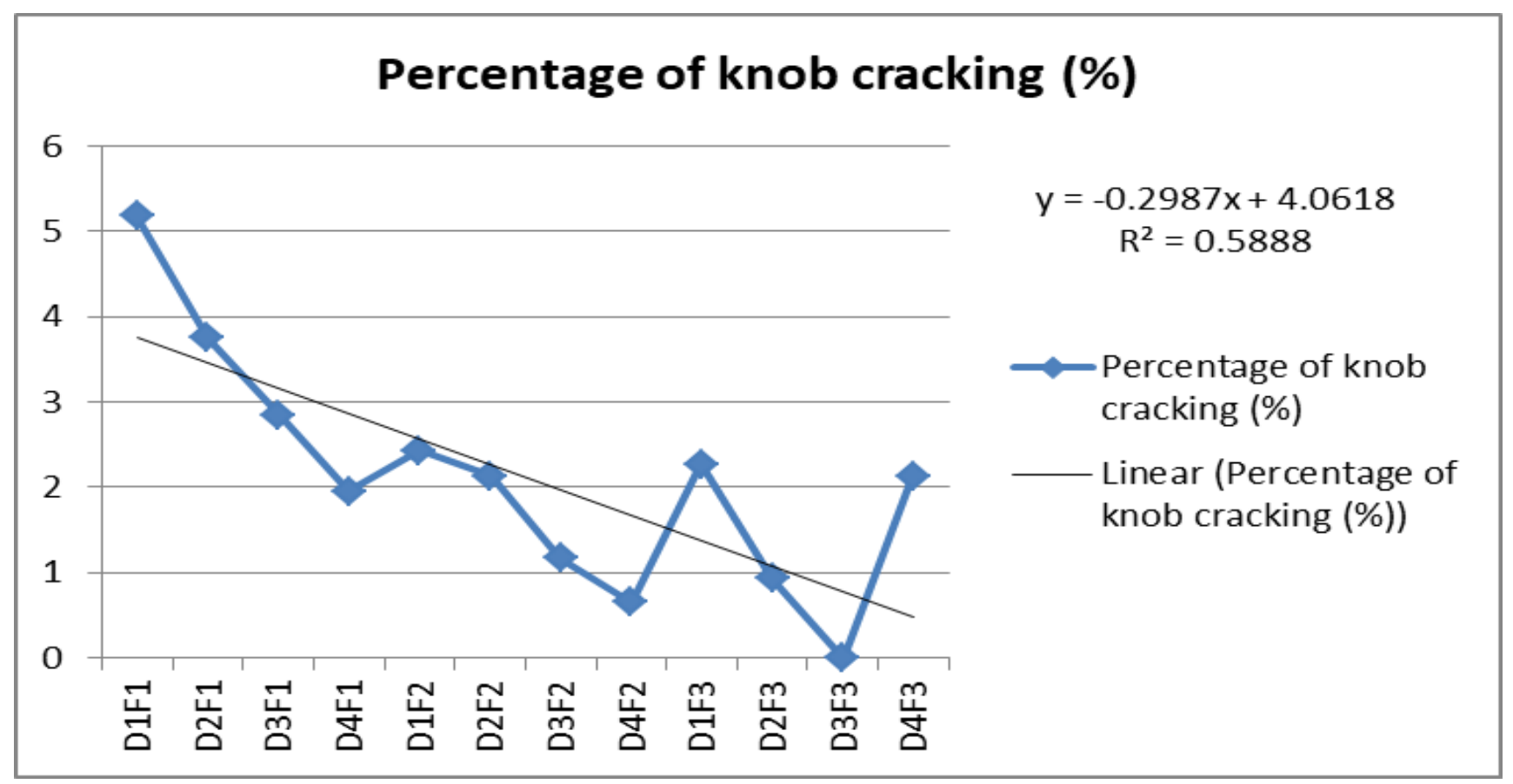

Figure.7 Residual effect of graded doses and frequency of boron application on percentage of knob cracking 
The treatment $\mathrm{D}_{3} \mathrm{~F}_{3}$ (residual application of $1.5 \mathrm{~kg}$ boron every year) which was significantly superior to all other treatments with no knob cracking.

These findings are also supported by Moniruzzaman et al., (2007), Abd EL-ALL (2014) and Ain et al., (2016) who found that broccoli grown in the absence of B showed initial signs of hollow stem which was reduced by adding $\mathrm{B}$.

Application of $1.5 \mathrm{~kg} / \mathrm{ha}$ boron (residual) every year significantly increased the values of total soluble solid content of knob, ascorbic acid content of knob, firmness of knob, dry matter content of knob, duration of maximum retention of shelf life of knob, percentage of marketable knobs with no percentage of knob cracking over control in Knol khol but residual application of $2 \mathrm{~kg} / \mathrm{ha}$ boron every year significantly decreased the values of total soluble solid content of knob, ascorbic acid content of knob, firmness of knob, dry matter content of knob, duration of maximum retention of shelf life of knob, percentage of marketable knobs and increase in the percentage of knob cracking which might be due to toxic effects of excessive application of boron.

On the basis of results of present investigation it is concluded that combined residual effect of different graded doses and frequency of boron application enhanced maximum value of quality and post harvest parameters of Knol khol var. white vienna like total soluble solid content, ascorbic acid content, firmness, dry matter content, duration of maximum retention of shelf life, percentage of marketable knobs with no Percentage of knob cracking in $1.5 \mathrm{~kg}$ boron (residual) applied per ha every year $\left(\mathrm{D}_{3} \mathrm{~F}_{3}\right)$ which was closely followed by $2 \mathrm{~kg}$ boron (residual) applied per ha in alternate year $\left(\mathrm{D}_{4} \mathrm{~F}_{2}\right)$.

\section{Acknowledgement}

We are thank ful to the Principal Investigator and scientists of AICRP on Micronutrient, O.U.A.T, Bhubaneswar for allowing and extending cooperation to do this research at $\mathrm{E}$ block of central research station, O.U.A.T, Bhubaneswar during 2017-18 under a long term project.

\section{References}

Abd EL-ALL, H.M. 2014. Improving growth, yield, quality and sulphoraphan content as anticancer of broccoli (Brassica oleraceaL. var. italica) plants by some fertilization treatments. Middle East Journal of Agriculture Research. 3(1): 13-19.

Ain, Q. Ayub, G. Ilyas, M. Ahmad, M. Begum, F.L. Saeed, A. Khan, M.I. and Shah, K. 2016. Response of broccoli to foliar application of zinc and boron application. Pure and Applied Biology. 5(4): 841-846.

Blevins, D.G. Lukaszewski, K.M. 1998. Boron in plant structure and function. Annual Review of Plant Physiology and Plant Molecular Biology. 49:481500.

Das, D.K. 2000. Micronutrients: Their Behaviour in soils and plants. Kalyani Publishers. Ludhiana.

Goldbach, H.E. and Wimmer, M. 2007. Boron in plants and animals: Is there a role beyond cell-wall Structure. Journal of Plant Nutrition and Soil Science. 170: 39-48.

Islam, M. Hoque, M.A. Reza, M.M. and Rahman, M.M. 2015. Contribution of boron doses on growth and yield of different broccoli genotypes. International Journal of Sustainable Crop Production. 10(2): 14-20.

Kumar, S. Chaudhury, D.R. Kumar, S. 2002. 
Effect of FYM, molybdenum and boron application on yield attributes and yields of cauliflower. Crop Research Hisar. 24(3): 494-496.

Mehrotra, D.M. and Mishra, P.H. 1974. Micronutrient deficiencies in cauliflower. Progressive Horticulture. 5: 33- 39.

Moniruzzaman, M. Rahman, S.M.L. Kibria, M.G. Rahman, M.A. and Hossain, M.M. 2007. Effect of boron and nitrogen on yield and hollow stem of broccoli. Journal of Soil Nature. 1(3): 24-29.

Odisha Agriculture Statistics Manual. 201617.

Saha, P. Chatterjee, R. and Das, N.R. 2010. Effect of foliar application of boron and molybdenum in sprouting broccoli (Brassica oleracea var. italic P.) under trai region of West Bengal. Research
Journal of Agricultural Science. 1(4): 335-337.

Satisha, G.C. and Ganeshamurthy, A.N. 2012. Micronutrient management in horticultural crops. 5th Indian Horticultural Congress. Punjab Agricultural University. Ludhiana. India, pp- 6-9.

Shah, D.A. Narayan, R. Ahmad, N. Narayan, S. and Wani, K.P. 2010. Influence of boron and zinc on growth yield and quality of knol-khol. Indian Journal of Horticulture. 67: 323-328.

Singh, K. 1991. Manurial requirement of vegetable crop. Indian Council of Agricultural Research, pp: 4-12.

Singh, R.N. Singh, S. Armakar, S. and Singh, S. 2002. Effect of boron application on cauliflower in an acid Alfisols. Journal of Research Birsa Agriculture University. 14: 61-63.

\section{How to cite this article:}

Rabi Shankar Panda, Dipika Sahoo, B. Jena, G.S. Sahu, P. Tripathy, R.K. Nayak, N.R. Sahoo and Das, M.P. 2019. Residual Effect of Boron on Quality and Post Harvest Parameters of KnolKhol (Brassica oleracea Var. Gongylodes L.) in Coastal Regions of Odisha. Int.J.Curr.Microbiol.App.Sci. 8(09): 343-352. doi: https://doi.org/10.20546/ijcmas.2019.809.041 